Article

\title{
Uncovering the Morphology of Kōm ad-Dikka in Alexandria
}

\author{
Mirhan Damir 1,2 \\ 1 Department of Heritage Conservation and Building History, Faculty of Architecture and Urbanism, \\ Bauhaus-University Weimar, Geschwister-Scholl Str. 8a, 99423 Weimar, Germany; \\ mirhan.damir@uni-weimar.de \\ 2 Department of Architecture, Faculty of Fine Arts, Alexandria University, Abd El-Salam Aref Str. 108, \\ Alexandria 21526, Egypt; mirhan.damir@alexu.edu.eg
}

Received: 1 September 2018; Accepted: 15 October 2018; Published: 24 October 2018

check for updates

\begin{abstract}
The historical residential area of Kōm ad-Dikka in Alexandria has experienced morphological transformation from the ancient era until the present. Each historical period had a physical impact on the city's urban structure that in turn struggled to survive the successive one with its different urban conception. However, the sinuous streets of this area, which probably date back to the late Egyptian Medieval period, are characterized as being the only surviving organic fabric intra-muros that was not altered during the Egyptian Modern period. In the absence of scientific publications regarding the history of Kōm ad-Dikka, this paper elaborately investigated its chronological history since the ancient era until the mid-twentieth century. Based on an in-depth investigation of historical maps and memoirs, this paper revealed the possible reasons behind the area's extant sinuous urban form and postulated reconstructions of its urban morphology through sequential phases.
\end{abstract}

Keywords: Alexandria; Kōm ad-Dikka; urban morphology

\section{Introduction}

Until the 1950s, Kōm ad-Dikka [1] consisted of two adjacent mounds: The western mound with the Crétin Fort where the Greco-Roman archaeological site was unearthed underneath, and the eastern mound where the historical neighborhood still stands [2]. This neighborhood is the main topic of this paper. In 2007, it was officially acknowledged in the National Registered Heritage Building List as a heritage area. The neighborhood is not only characterized by its location at the only artificial mound in the historic city center of Alexandria, but also by its dominant extant medieval sinuous street structure that is surrounded with integrated traces of the westernized orthogonal street pattern. The irregular and organic street structure of this neighborhood, with its small parceled late Ottoman buildings, is predominantly similar to those of the so-called Turkish Town [3]. And although there have been multiple publications regarding the rich urban and architectural heritage of the Turkish Town, no scientific research was undertaken regarding the documentation of the history of Kōm ad-Dikka. This study is an attempt to document its yet uncovered urban history.

Regarding the origin of the name Kōm ad-Dikka, a number of published historical literature refer to it as Kom el Dekka [4], Kôm El-Dik, Kom el Dikk, Com-el-Dikkéh, and Com-el-Dikeh [5], which derive from the Arabic language: The word Kōm means a stack, and ad-Dikka signifies a bench [6]. The ancient Greek geographer Strabo describes a height where one can view all of Alexandria over its hilltop [7]. This information is also confirmed by the engineer and astronomer Mahmoud-Bey al-Falaki [8]. The older inhabitants of the neighborhood report that rooster fights took place on the mound in the past. Hence, the mound's name evolved from Kōm ad-Diākah, 
deriving from the Arabic word Dīk, namely a rooster. This announcement is confirmed by the French physician Clot-Bey, where he identified the quarter as Kom-el-Dyck and Coline du coq [9].

Unlike the Turkish Town which morphed and developed outside the city's ancient and medieval city walls, the area of this study is regarded as the only settlement-intra muros-where its urban characteristics were bordered and not eliminated by the new westernized urban conception. Nevertheless, this tangible aspect of Kōm ad-Dikka has received tenuous attention in the scientific literature. On one hand, former scientific publications were mainly carried out on the archaeological site, namely the former western mound; on the other hand, there is scarce publication on the history of the eastern mound. In the modern literature, it is in 2007 that the American researcher Judith McKenzie briefly refers to the neighborhood of Kōm ad-Dikka in her book "The architecture of Alexandria and Egypt c. 300 BC to AD 700". Based on an illustration in McKenzie's book that presents a site section of the current archeological site in relation to the eastern mound and current neighborhood of Kōm ad-Dikka, McKenzie consolidates the hypothesis that the archaeological site extends below the current historical neighborhood and that it might have had the same residentiary function during the ancient time. This illustration is captured from the publication of polish archaeologist M. Rodziewicz "La Stratigraphie de l'Antique Alexandrie à Lumière des Fouilles de Kôm el- Dikka". In the book of the Arab engineer and astronomer Mahmoud El-Falaki "Mémoire Sur l'antique Alexandrie, Ses Faubourgs et Environs Découverts, Par Les Fouilles, Sondages, Nivellements et Autres Recherches" in 1872, he only mentions busy roads with property in the area of "Com-el-Dikeh". Given the lack of archaeological evidence in situ, as well as reliable publications with comprehensive information about this historical residential area, the methodology for this study relied on a critical investigation of historical maps, historical memoirs, and publications.

\section{Materials and Methods}

The historical investigation of Kōm ad-Dikka is the pivotal subject of this paper and is explored based on credible primary sources. To thoroughly understand the urban morphology of Kōm ad-Dikka, this paper is divided into two main parts: The first part is a descriptive investigation of the scrutiny of its chronological urban history, where each historical urban form is reflected by its urban ideology. The investigation of this part is conducted by critically comparing historical maps with concurrent memoirs and relevant secondary literature. Each of these data are critically chosen based on their liability, as well as their visual and narrative credibility to represent the chronological phases of the research site in relation to its subsequent one. This part served as the chronological framework on which the second illustrative part of the paper was based.

As a result of the first part of this paper, the second part proposes a perceptive reconstruction of the urban morphology of Kōm ad-Dikka. By analyzing the site's urban fabric in the illustrative historical maps, guided as primary sources, five interpretive graphical maps are composed. These maps are an attempt to better visualize and understand the different subsequent urban ideologies and the extent of their influence on each other.

This paper opens up new research ideas on historical comparative investigations in similar urban forms; it aims at shedding light on the physical urban regeneration which occurred in the city of Alexandria, especially during the Egyptian medieval period.

\section{Methodology}

This part comprises Kōm ad-Dikka's chronological urban history. It first uncovers its urban form during the ancient times; it then depicts the early evolution of its sinuous structure during the Egyptian medieval period, and lastly represents its integrated westernized street structure by the Ninetieth Century.

After the Early Arab conquest by the Sixth Century AD, the ancient city of Alexandria lost its ancient global cultural prominence; however, it managed to mainly maintain its status as a Mediterranean entrepôt under the Arabs' authority [10]. By appointing Fuṣtat as the new capital 
of Egypt, building materials were used as spolia to build the new capital, thus leading to a gradual physical state of decay of the once monumental ancient city. It was left in ruins, especially after a number of destructive earthquakes. With their sinuous urban conception, new Arab settlements developed on top of the ancient one. Stratigraphically, the existing block of Kōm ad-Dikka lies above the ancient city layer of Alexandria.

\subsection{The Hippodamian Salient Features of Kōm ad-Dikka}

The first systematic archaeological study of ancient Alexandria began in the Nineteenth Century when El-Falaki was commissioned by Khedive of Egypt Ismail Pasha to submit a reconstruction of the ancient city. Ancient Alexandria was designed by Dinokratous, the architect, and advisor of Alexander the Great. By examining the aboveground ruins, the Hippodamian grid plan, as well as the ancient quarters of the city, was identified and mapped. This reconstruction attempt was revised by the end of the Nineteenth Century by the German archaeologist Ferdinand Noack [11].

By overlaying both reconstruction attempts with the current map of Kōm ad-Dikka, some of the reconstructed Hippodamian streets correspond to its current street raster (Figure 1) [12]. According to the map of El-Falaki, the current neighborhood lies approximately $2.5 \mathrm{~km}$ to the west of the former eastern Canopian city gate and about one kilometer to the north of the southern ancient city wall. The four enclosing streets of the neighborhood area overlap the Hippodamian grid: Horizontally the Fouad street with the ancient L1 from the north and traces of the ancient L'2 with 'Omar Tusun Street from the south. Vertically, Dr. Ibrāhīm 'Abd as-Saiyid street overlaps the R2 from the east, and Sīdi Quštum street the ancient R3 from the west. The location of the main orthogonal grids also matches with the map by Ferdinand Noack. Noack improved El-Falaki's map by reconstructing the Hellenistic secondary grid raster. Each orthogonal street grid is rectangularly shaped, and represents a neighborhood consisting of 18 insulae, rationed 1:2 [13]. The grid of some of this insulae matches the grid of this paper's study area.

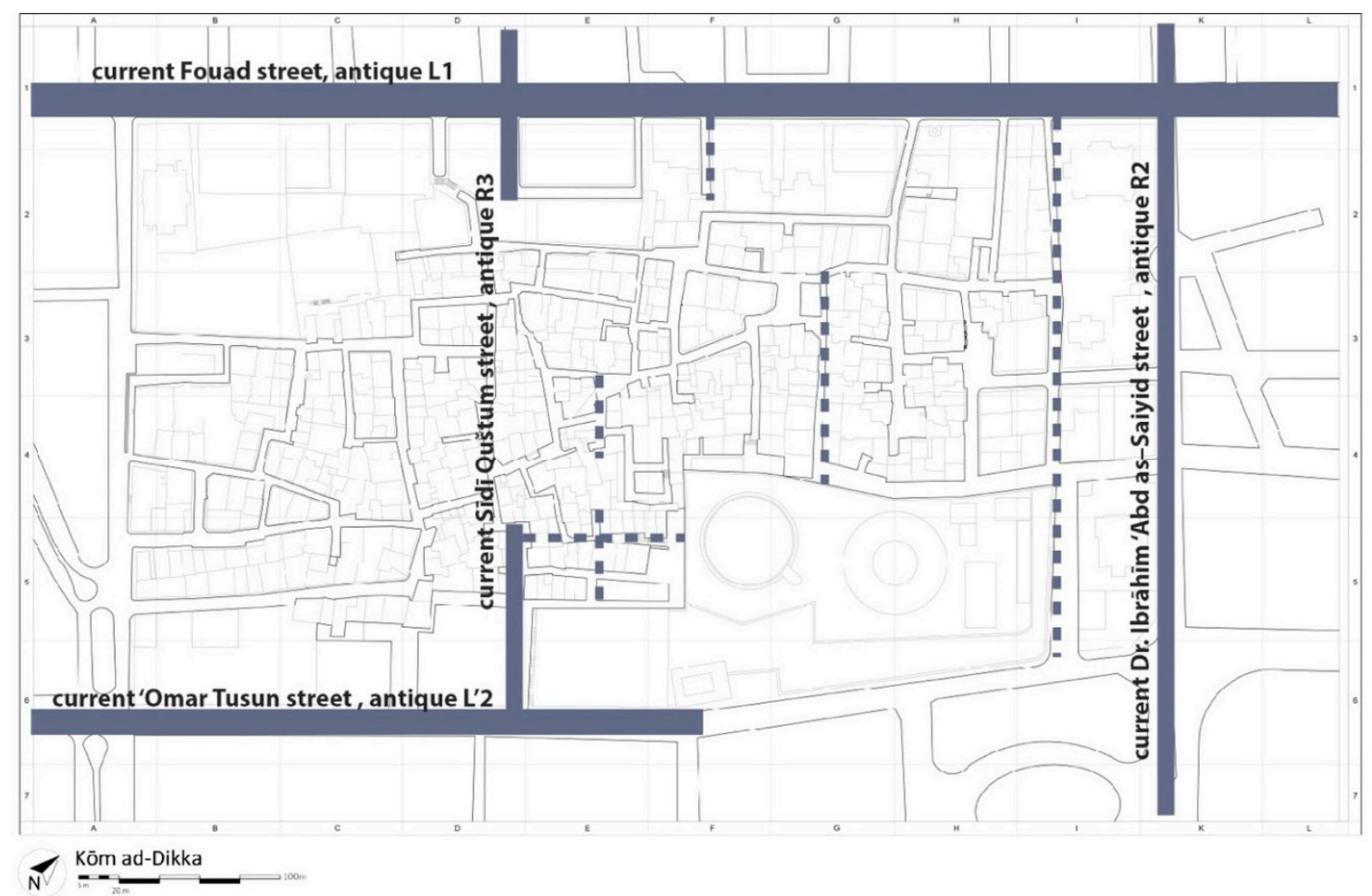

Figure 1. Map of present Kōm ad-Dikka with overlapped matching reconstructed ancient streets by both al-Falaki and Noack (overlapping reconstructed insulae by Noack in dashed lines). Edited by author. 
El-Falaki divided Alexandria into five districts on his map; he marks contour lines on the location of the two mounds of Kōm ad-Dikka and refers to them as Paneum [14], based on the description of Strabo. He describes the Paneium as a man-made hill: 'Here, too, is the Paneium, a "height", as it was, which was made by the hand of man; it has the shape of a fir-cone, resembles a rocky hill, and is from a spiral road, and from the summit one can see the whole of the city below it on all sides' [15]. Since 1960, the Polish Center for Mediterranean Archeology was commissioned to undergo an archaeological survey on the western artificial hill, located about $20 \mathrm{~m}$ above sea level. A large Greco-Roman archaeological complex was uncovered $12 \mathrm{~m}$ below sea level. The Polish team did not find any evidence of the Paneium. Among their successful findings was the ancient road R4, situated on the same location indicated on both maps of El-Falaki and Noack. On the east side of the excavated street R4, the archaeologists discovered ruins of a Greco-Roman neighborhood dating from the 1st until the Third century AD [16]. This neighborhood extends beyond the eastern border of the archaeological site and thus its ancient actual area cannot be estimated. It is therefore claimed that the rest of the ancient neighborhood area extends further to the east underneath the present neighborhood [17]. And since it is densely inhabited, no excavations took place to justify this claim; until now the nature of the ancient area below remains unknown.

\subsection{Kōm ad-Dikka and the Early Medieval Egypt}

When the city of Alexandria was conquered by the Persian king Khosrau in 619 AD and then came into possession of Khalif Omar in $642 \mathrm{AD}$, Alexandria sank into insignificance compared to its ancient stature [18]. When the Arabs founded Fustat, today's Cairo, as the new Egyptian capital, Alexandria's role was limited to the port as a gateway to the Mediterranean trade which has always been pivotal to the city. Accordingly, new land was silted up by the port on the Heptastadion with extra muros to comply with the new city role. Intra muros, the ancient city, suffered drastic topographical changes due to earthquakes, tsunamis, as well as the maintenance neglection of the ancient water system. Scarcely inhabited, the ancient city walls shrunk [19]. According to the Egyptian historian As-Saiyid Abd al-'Azīz Sālim, the Arab military commander, Amr Ibn al-Āas brought seven Arab tribes to take Alexandria as their new home, after the Sixth Century. Among them was the tribe of Lahm, which settled in Kōm ad-Dikka to best guard the city on its hill. However, it is not specified whether the Lahm tribe inhabited the eastern or western mound [20].

On the western hill, Polish archaeologists revealed three superimposed necropolises dating back to the Egyptian medieval period: The so-called lower necropolis from the Umayyad and Abbasid dynasties between the Eighth and Tenth Centuries, the middle necropolis from the Fatimid dynasty in the Eleventh Century, and the upper necropolis from the Ayyubid dynasty from in the Twelfth Century. At that time, the ancient ruins were reused as burial chambers and tombstones [21]. It is assumed that the same stratigraphy is located underneath the neighborhood, especially due to the shrines still standing in it [22].

The soil of the three necropolises in the archaeological complex consisted mostly of rubble and debris from the Muslim period. This was described by travelers like Nicolas Martoni in 1394, who illustrated the area as an artificial hill consisting of masonry and houses wreckage. The Andalusian traveler Léo Africanus compared the artificial hill with the Roman Testaccio and reported fragments of antique vases [23]. During the 1950s, the Polish team uncovered ruins of Arab huts with animal enclosures along with the middle necropolis [24]. This denotes that during the Fatimid dynasty a small settlement existed next to the cemeteries. However, it cannot be verified whether the same settlement also existed underneath the current neighborhood at the same period. The early development of the current urban fabric of Kōm ad-Dikka presumably morphed before the end of the Eightieth Century, most likely at the beginning of the Sixteenth Century.

\subsection{The Metamorphosis of Kōm ad-Dikka}

During the Egyptian medieval period, Alexandria faced drastic urban changes. Over the years, a new urban settlement was created by the harbor, transforming the Heptastadion into an urban 
settlement. Since this settlement mainly morphed during the early Ottoman period, it was referred to as the Turkish Town. In historical maps, the Turkish Town is marked as Alexandrie Nouvelle, where the settlement intra muros was named Vieille Alexandrie [25].

\subsubsection{The Hypothetical Vestige of Early Urban Morphology}

There is no direct evidence to indicate the origin of the sinuous urban fabric of Kōm ad-Dikka. La description de l'Egypt was the first documentation to publish accurate 2D maps of Alexandria; maps from 1798 show the main sinuous street pattern. The morphology origin of the urban fabric before that year can only be hypothetically derived with the help of medieval travelers' memoirs and isometric maps. One of these maps is made in 1566 by the German Orient traveler Johann Helffrich; based on this map, an assumptive inkling of the urban genesis of the historical area can be derived (Figure 2) [26]. On Helffrich's map, a noticeable scene is illustrated within the city wall: A water channel runs with close adjacent buildings on both of its sides and with an access gate located over the channel, at both edges of the buildings' alignment. Bridges are drawn to indicate crossings from one side to the other, yet his textual description does not mention any water artery. Therefore the artery with bridges can presumably indicate a road, under which runs a water channel. Johann Helffrich identifies this illustrated scene as a bazaar, consisting of caravanserais and boutiques. In his travel diary, he reports that upon his arrival from Cairo through the eastern Rosetta Gate in Alexandria he stayed in the French Fonticum that was located by the eastern city gate. He describes this Fonticum as a two-story rectangular caravansary with courtyard dedicated for foreign merchants. At night, the doors of the bazaar are closed and protected by an Arab guard [27].

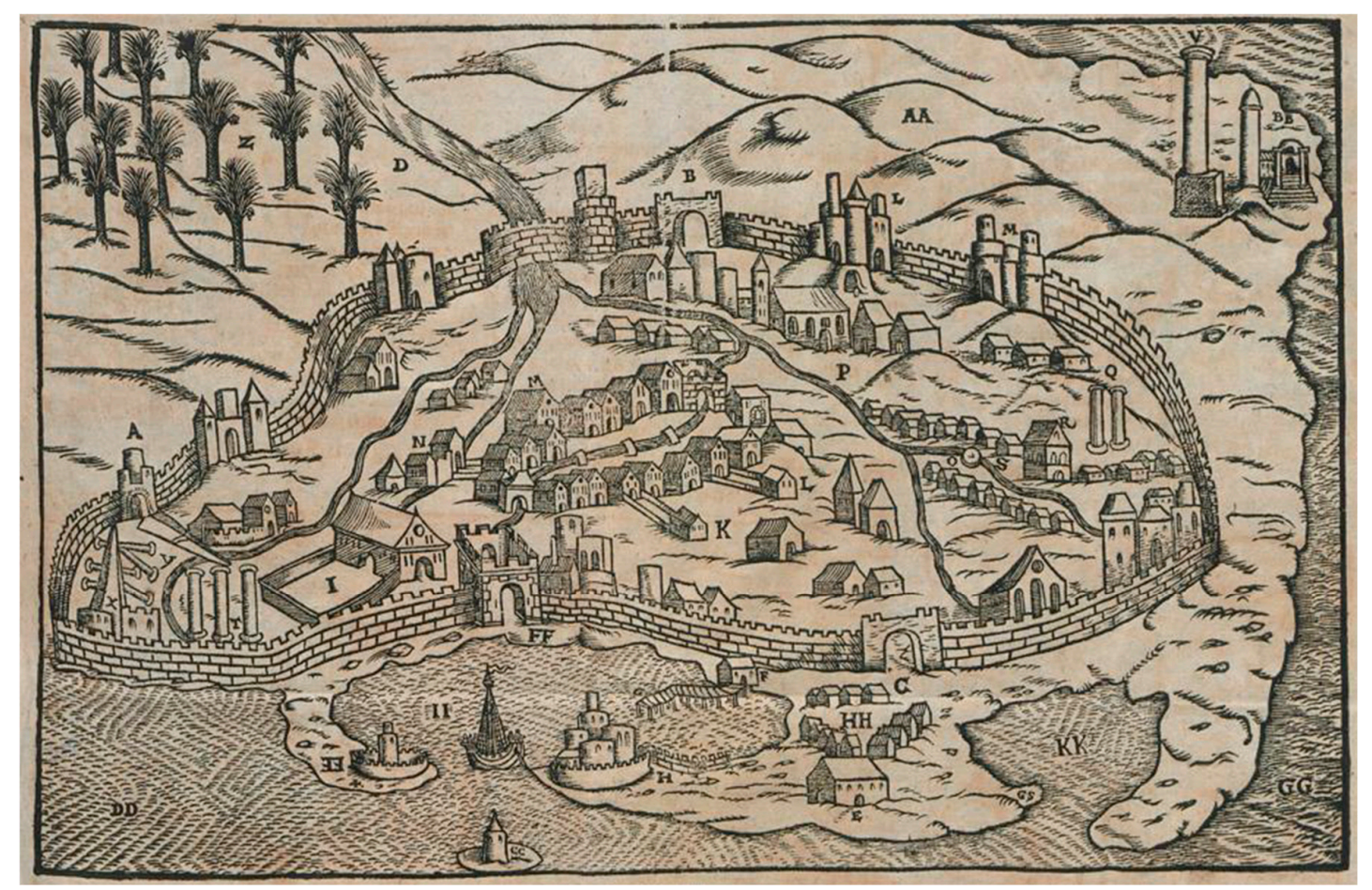

Figure 2. Map of Alexandria by Johann Helffrich, 1566.

In the Twelfth century, Alexandria regained its role as an important port and trade city. Since European trade was not allowed in Cairo, Alexandria grew into an important trading hub connecting the East with the West [28]. Through the centuries, merchant houses developed for foreign merchants and by the end of the Seventeenth Century, these took the form of caravanserais and boutiques, located and developed inside the city walls, especially by the city gates. Due to the shrinkage of the city wall during the Egyptian medieval period, the distance between the eastern 
border of Kōm ad-Dikka and the eastern Rosetta Gate decreased to about $350 \mathrm{~m}$. The southern course of the Arab city wall ran on the antique L'2 street, where the southern 'Omar Țusun street, of today's neighborhood, is currently located. According to the Ottoman explorer Evliya Çelebi, 100 boutiques took place by the eastern Rosetta gate, near which lay the artificial mound [29]. These were either owned by indigenous or foreign merchants; each of these structures was surrounded by a settlement of gatekeepers and porters, located next to or around the trading area [30].

When the Turkish Town developed extra muros by the end of the 17th century, new caravansaries and boutiques were structured on this peninsula. Merchants moved from the bazaars intra muros to the newly populated area on the silted land. This may have caused great decay to the ones intra muros; the once lively trading facilities at the city gates might have been later populated by poorer inhabitants due to new habitation in the Turkish quarter. These poorer inhabitants were presumably the poorer traders or gatekeepers and porters who lived next to the bazaar.

\subsubsection{The Detectable Phsyiognamy of Kōm ad-Dikka}

In 1798 the engineers of l'armée d'orient of the French Expedition created the first accurate map of Alexandria with its settlements and urban features (Figure 3) [31]. The largest populated settlement intra muros was located by the eastern city gate and can be divided into two areas: The first located directly at the Rosetta gate extending on both sides of the traces of the ancient road L1 [32]. The second area is located southwest from the first area on the artificial hill where the extant sinuous urban fabric of Kōm ad-Dikka is located [33]. By analyzing historical maps and memoirs, two hypotheses can be displayed regarding the origin of the current urban fabric. The first hypothesis develops from the German orient traveler Johann Helffrich's map in 1566. The bazaar spine illustrated by Helffrich with the street gates is not indicated on any later-produced maps. Nevertheless, it is possible to make a presumption from his map, comparing it with maps from 1798, 1801, and the present condition. The historical map from 1801 represents the main outline of the historical area with its diagonal running spine, namely the present street of Saiyid Darwīš. During the Sixteenth Century, two opposing rows of boutiques with caravanserais formed a street, called a bazaar. During his trip to Alexandria in 1643, the French traveler Gabriel Brémond described the bazaars as settlements inside the city walls, each consisting of a commercial street accessible from both ends by gates. The bazaar contained houses, boutiques, and caravanserais. In the bazaar, various goods are sold by the merchants who also live in the same buildings. At the end of the day, the doors of the caravanserais, the boutiques and the street gates are closed and are guarded overnight [34]. The previous name of the street of Saiyid Darwǐš was Sūq Kōm ad-Dikka [35]. The Arabic word Sūq means market or bazaar; this may be an argument that this street was probably originally one of the bazaar streets that Helffrich reported of. This diagonal street can be interpreted from the examination of the maps of 1798 and 2013 as the main access road, on which the quarters have developed structurally. On the isometric map of the English traveler Richard Pococke from 1743, the second hypothesis can be deduced. Pococke illustrates the settlement area by the Rosetta gate; only indicating it as a mound, Pococke identifies the mound as 'Porters' Hill' [36]. This contradicts the claim that today's neighborhood was originally a bazaar. It can be assumed that the hill was inhabited by the porters who worked for the merchants in the bazaar [37].

Nowadays, the oldest buildings in the area date back to the late Ottoman period. It is stylistically similar to the ones in the Turkish quarter. The urban fabric is probably the only surviving element from the medieval period until before the late Ottoman period [38]. Presumably, the medieval structures of the historical neighborhood deteriorated with the development of the Turkish Quarter by the end of the sixteenth century. Similar to the ancient era, the bazaar building materials may have been reused elsewhere, possibly for the construction of the new ones in the Turkish Town.

The German traveler Johann Michael Vansleb reports in his memoir that in 1672, the French built a garden planting project within the city walls that they called Jardin du Marchand [39]. On the historical maps of 1798 and 1801, such gardens are illustrated around Kōm ad-Dikka. A map in 1848 by Lemaitre illustrates the southern part of the outlines of the settlement and refers to it as Jardins [40]. 
This historical habitation might have developed into a village-like settlement, whose poor inhabitants were engaged in limited trade and agricultural work; this is pictured on the historical photograph of 1905, entitled Village de-Kom-el-Dick, which probably shows its southern area (Figure 4). This area continued to develop, while preserving its urban pattern until the first half of the Nineteenth century.

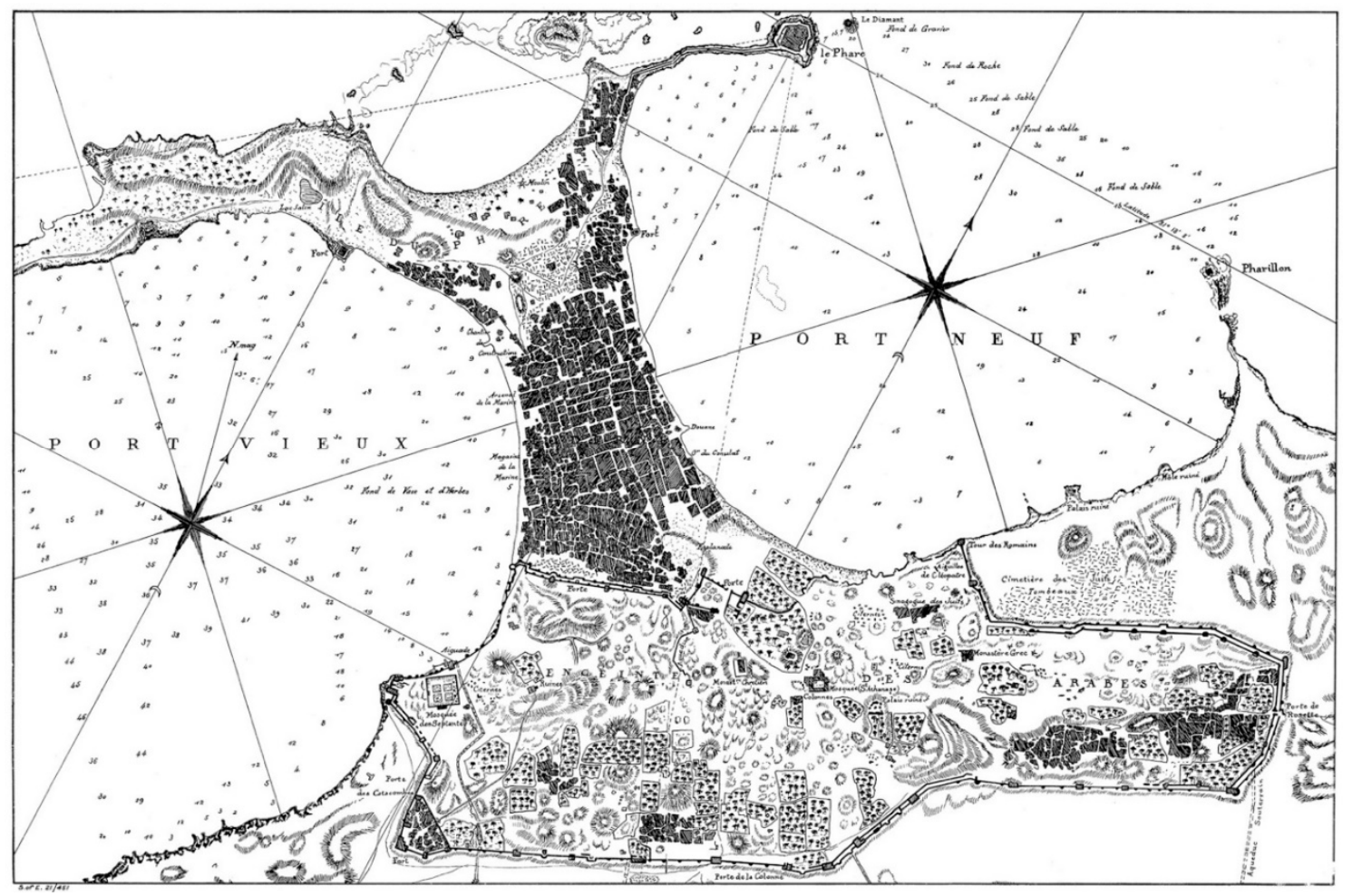

Figure 3. Map of Alexandria by the engineers of l'armée d'orient of the French Expedition, 1789. The location of Kōm ad-Dikka is pointed out with arrow.

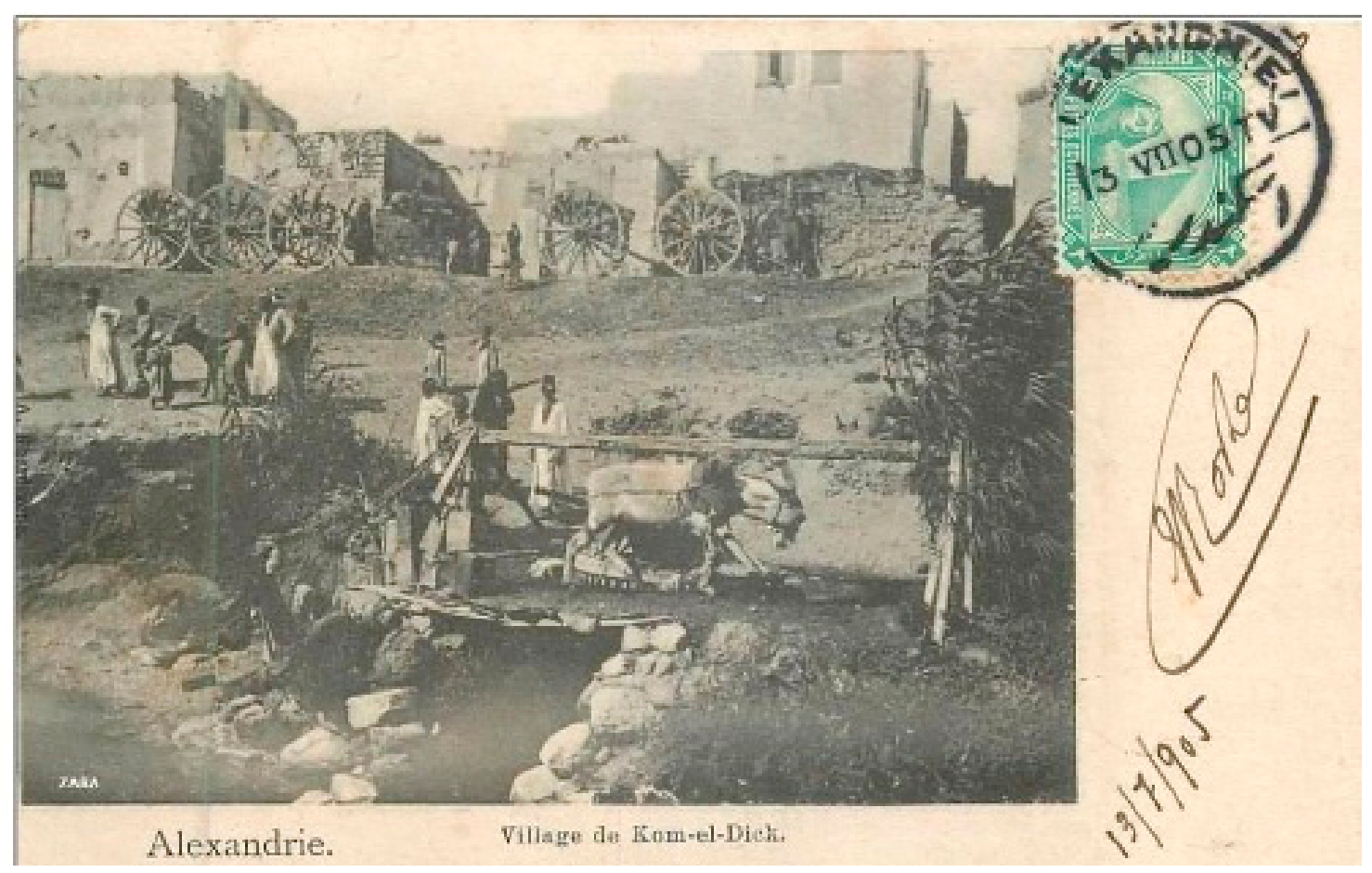

Figure 4. Postcard of Alexandria of the village of Kōm ad-Dikka, signed in 13 July 1905. 


\subsection{Kōm ad-Dikka and the Urban Westernization}

The foundation of modern Egypt began in 1805 by Mohammad Ali Pasha, who was appointed as Wālī of Egypt by the Ottoman Empire. By 1805, Alexandria was a harbor city with about eight thousand inhabitants, who mostly lived on the Turkish Town [41]. In 1824, the first city planning institution of Alexandria, Le Conseil de l'Ornato, was initiated and commissioned to provide new urban and architectural regulations [42]. And since the Turkish Quarter was densely built and inhabited, the Ornato regulations were actively implemented within the city walls' settlements.

As a tool to colonial influence, the Ornato regulated European-like urban and architectural structures to best accommodate the modern commercial traffic, thus attract Europeans to Alexandria. The indigenous inhabitants lived in so-called bidonvilles as artisans, merchants and peddlers. They were mainly categorized by their congested density and by the residual epidemics that hit the city during the medieval period [43]. For this reason, the new westernized ad hoc urban planning scheme destroyed most of the structures and settlements intra muros, except the neighborhood on the eastern mound.

The historical map of 1855 by Charles Muller shows the first implementations of le Conseil de 1'Ornato: The northern part of the city wall has been demolished and a new orthogonal urban structure has been implemented, based on European urban ideologies. It is interesting to notice that Kōm ad-Dikka is the only remaining urban pattern intra muros drawn on the map (Figure 5). In former historical maps of Alexandria, the historical area is characterized by the number of Maqām, namely the shrines of Muslim saints, which still stand until today, as well as its recognition as porters' hill.

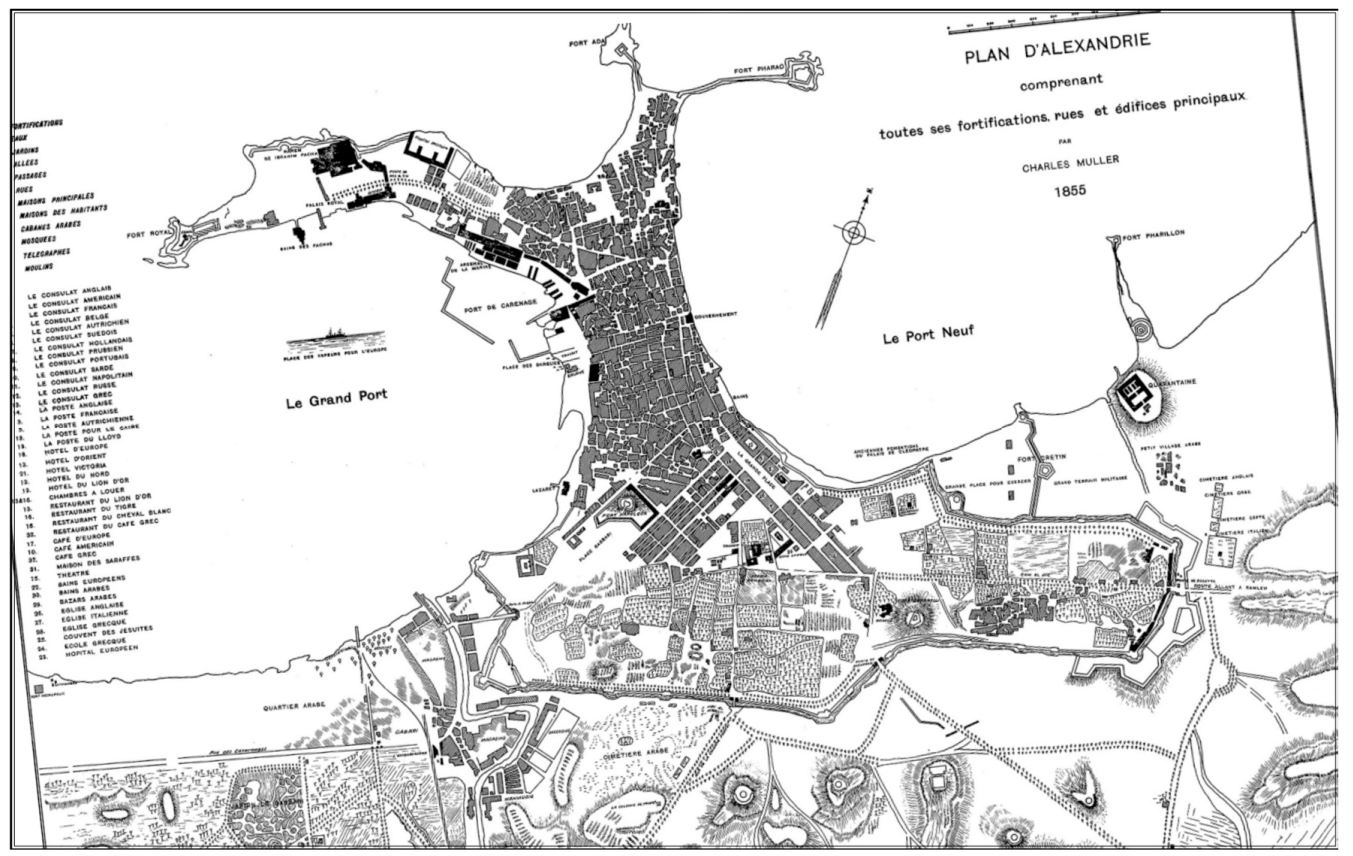

Figure 5. Map of Alexandria by Charles Muller, 1855. (rotated by author). The location of Kōm ad-Dikka is pointed out with an arrow.

It was not until the second half of the nineteenth century that Alexandria's new European urban developments extended to the area of Kōm ad-Dikka. This is seen on the historical city map of Les Services Techniques de la Municipalité in 1902 (Figure 6). Its new displayed settlement is referred to as the Latin Quarter, in Arabic al-Haiy al-Latīnī, where its urban form is largely adapted to the ancient urban traces. The residential area, whose urban pattern dates back to the medieval period did not coincide with the Ornato development plan and replaced by the westernized street course. Nevertheless, these urban constructions enclosed the populated settlement to prevent the 
visual distraction from the new westernized European city appearance; this also prevented its further urban extension. This urban enclosure does not only exemplify a connection of two different urban conceptions but also the relationship between two social strata: The richer inhabitants in the orthogonal new urban settlement, in Arabic known as kharij al-hukuma, encompassing the organic residential quarter populated by the poorer residents, in Arabic known as dakhil al-hukuma [44]. The factual argumentation behind the perpetuation of Kōm ad-Dikka remains unknown. Hypothetically, it is possible that its location, on the artificial hill, did not stand in the way of the Ornato's urban planning development. Additionally, the existence of a poorer settlement next to the richer one might have created a social coherence, where the poorer labors lived and worked next to wealthy elite [45]. The same concept can be historically derived from the porter's hill, indicated in previous maps. The same practice might have been regenerated for the same purpose but with a new interpretation.

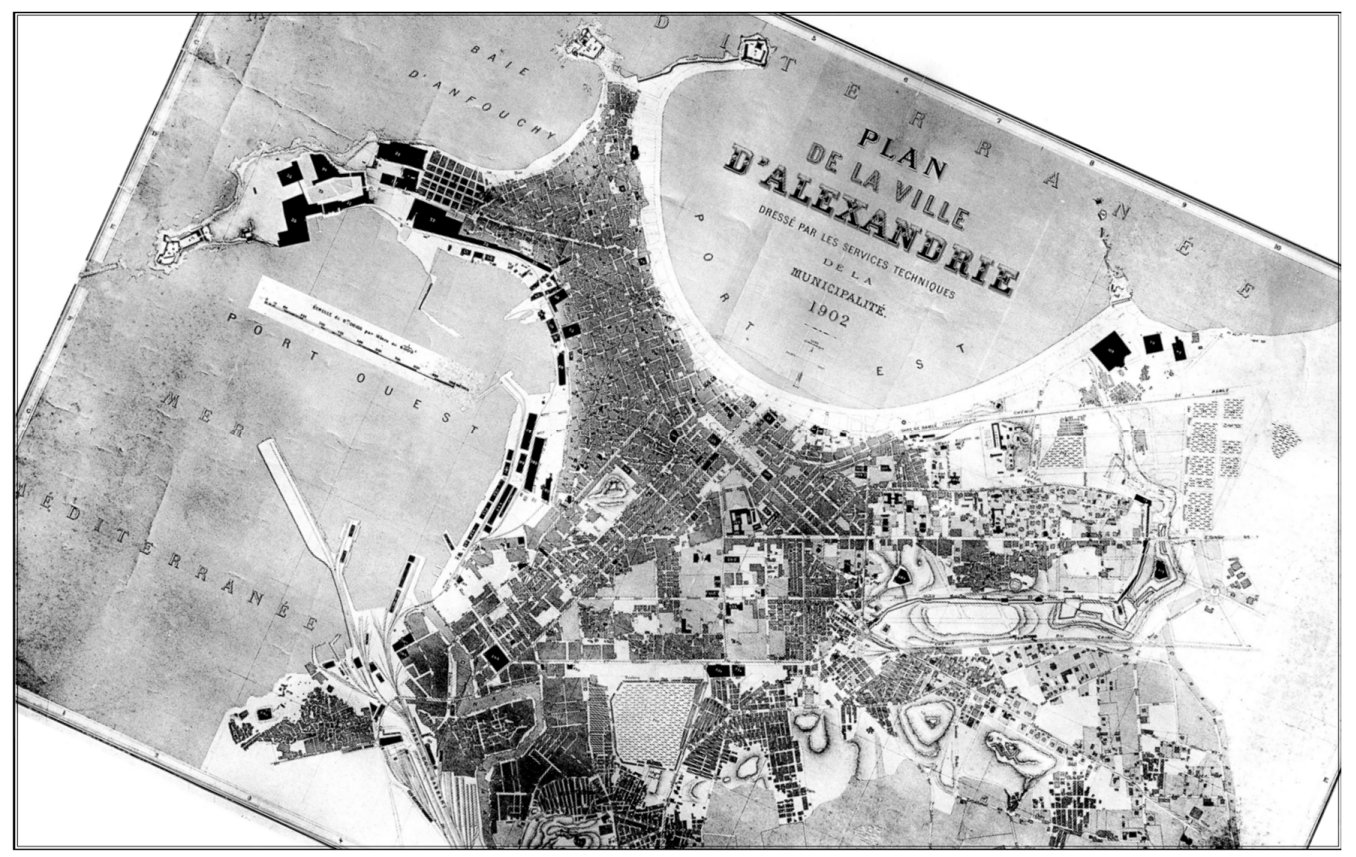

Figure 6. Map of Alexandria by the municipality's technical service, 1902. (rotated by author). The location of Kōm ad-Dikka is pointed out with arrow.

\section{Results and Discussion}

Kōm ad-Dikka has developed through different time spans and urban styles. This derives from the historical investigation mainly based on the historical maps. The former parts of this paper comprised a narrative elaboration of the history of the neighborhood. This part of the paper, however, is an attempt to interpretably reconstruct its urban morphology in different phases. The morphological phases are conceptualized based on historical maps, reconstruction attempts, and travel book descriptions, and are accordingly divided into five morphological phases. The first two phases represent each a time cycle due to the lack of reliable references, as well as the similar cartographic similarities in the reliable ones. The remaining phases - the third to the fifth-are each relatively divided into approximate time intervals. These are also based on the illustrated historical city maps since the French expedition in 1798. This reconstruction portrays the development of the urban pattern since the antique era until today, even if it is not stratigraphically successive.

\subsection{First Morphological Phase}

The first phase encompasses the Hippodamian traces of the antique Alexandria (Figure 7a). The streets' pattern is based on the reconstruction maps of El-Falaki and Ferdinand Noack. These correspond to the current main access streets of the neighborhood: Fouad street from the 
north, Ibrāhīm 'Abd as-Saiyid street from the east and the western part of the southern 'Omar Tusun street. Based on his reconstruction map of antique Alexandria, Ferdinand Noack illustrated the insulae and their side streets, from which the current ad-Damāmīnī street overlays one of them. There is as yet no clear evidence of the ancient urban character of the current Kōm ad-Dikka; however, the exploration of the reconstruction maps of Noack and al-Falaki, the historical publications, and the reports from the Polish archaeologist provide the impetus for assuming an ancient neighborhood character more than one of a Paneium.



(a)

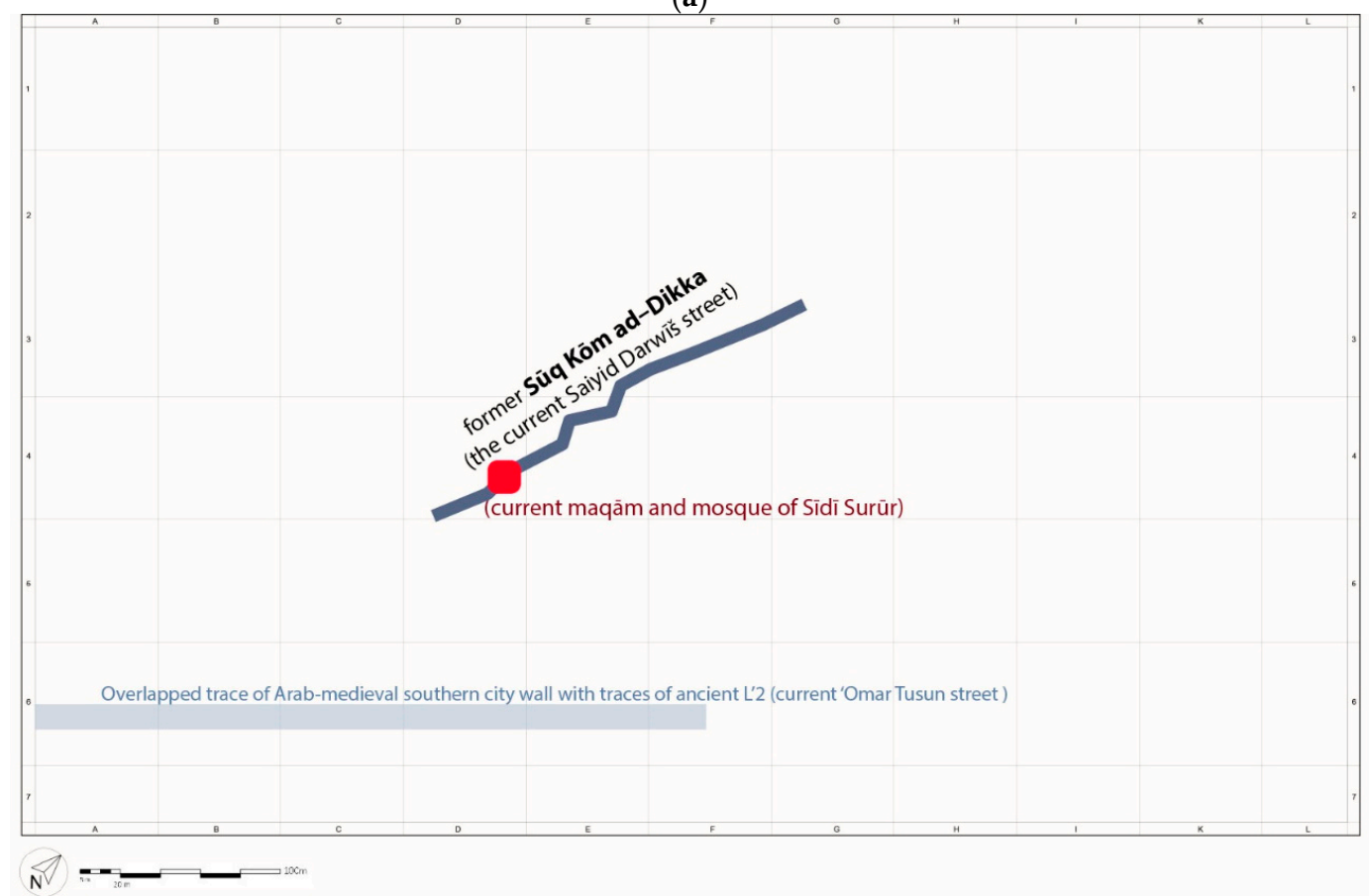

(b)

Figure 7. Cont. 


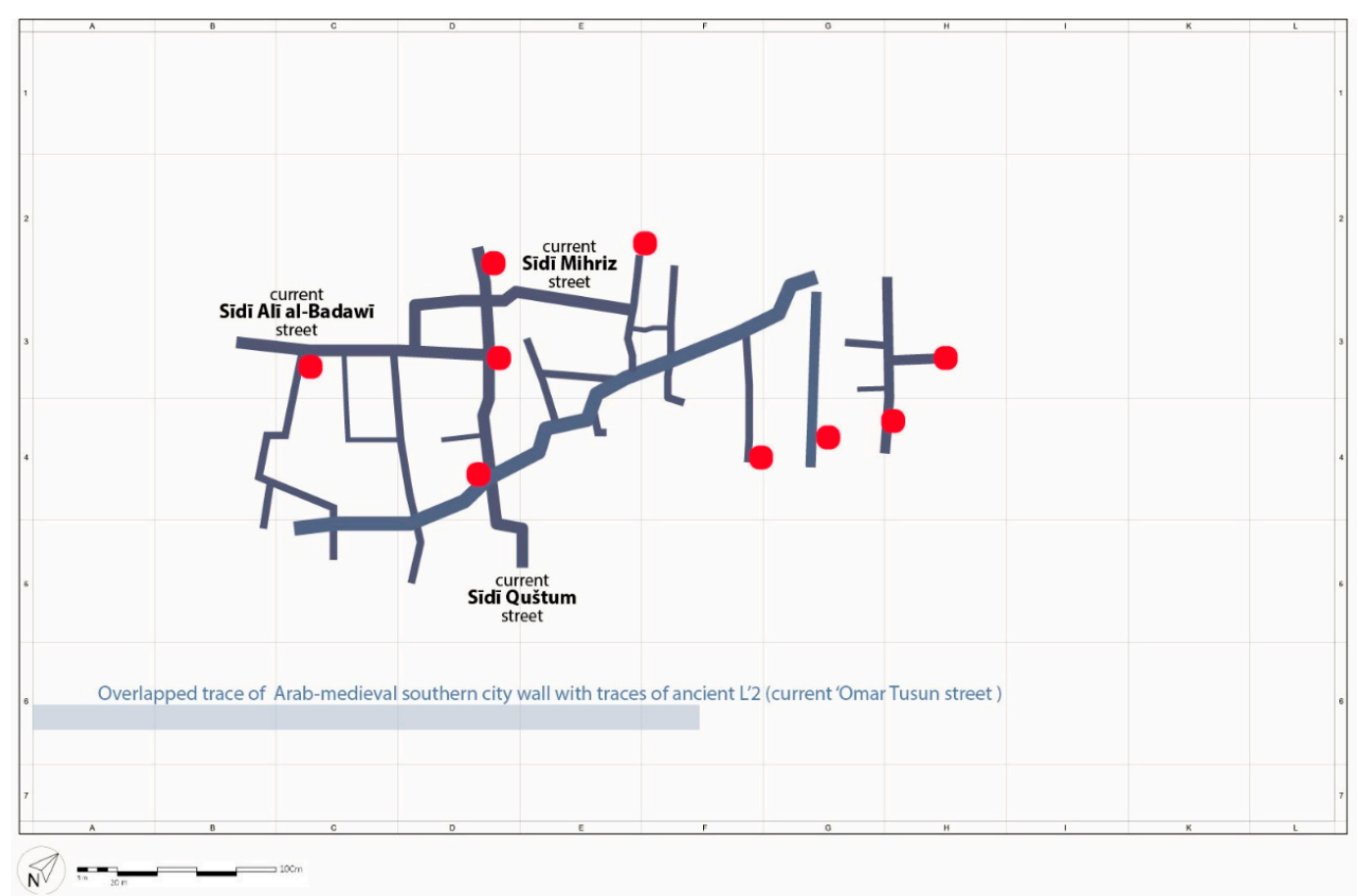

(c)

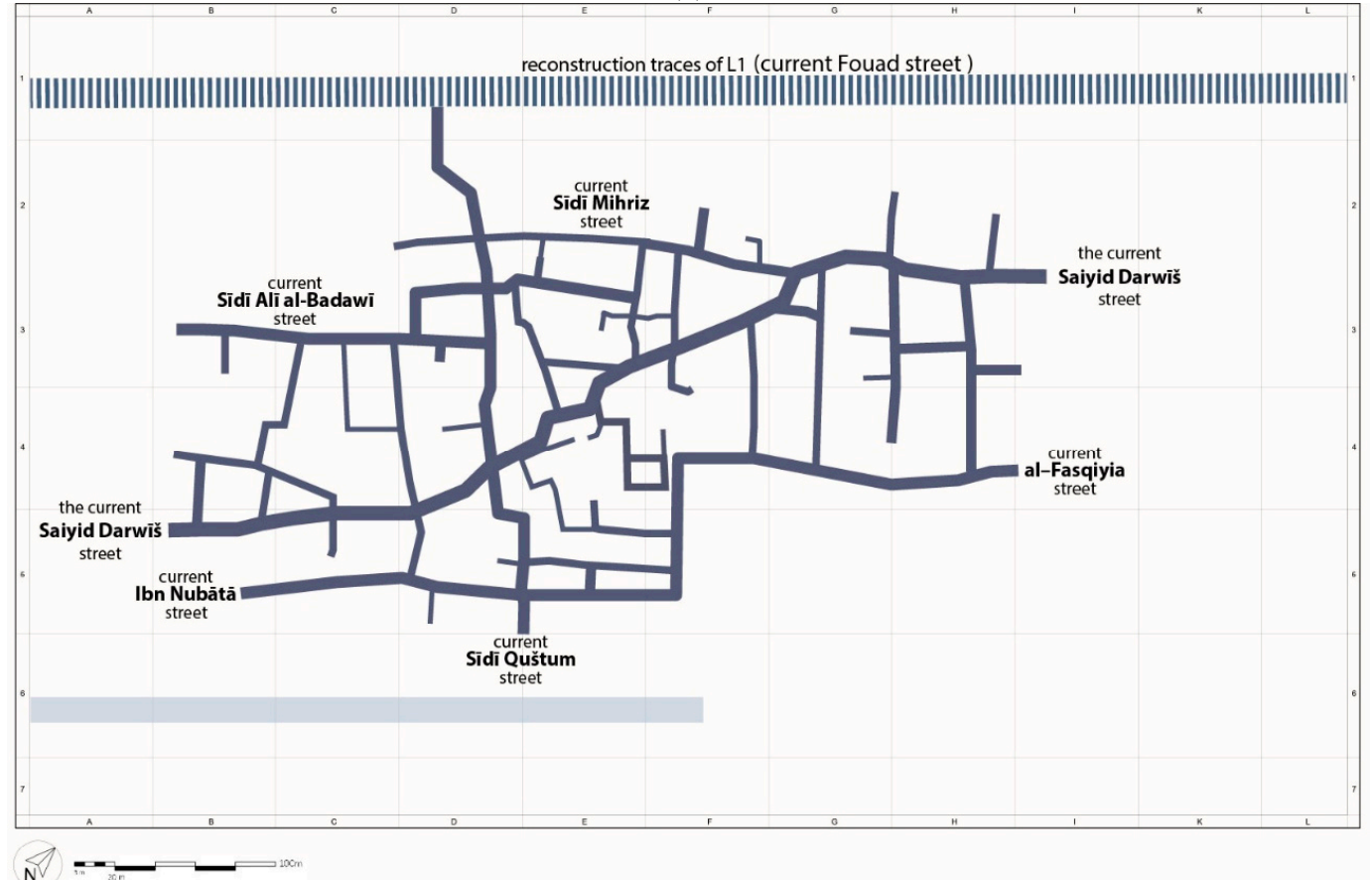

(d)

Figure 7. Cont. 


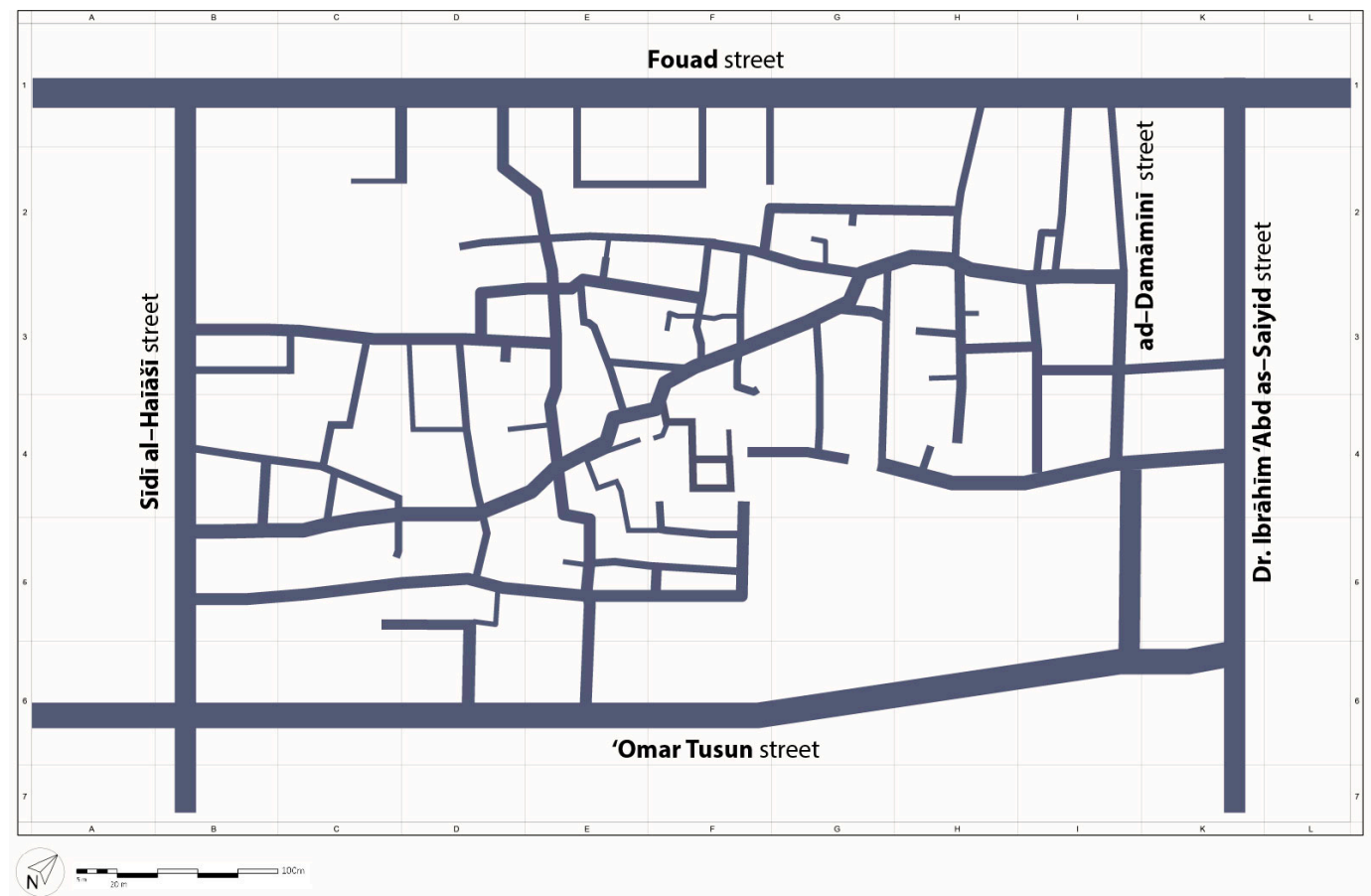

(e)

Figure 7. (a) Kōm ad-Dikka. Reconstruction of phase 1; (b) Kōm ad-Dikka. Reconstruction of phase 2; (c) Kōm ad-Dikka. Reconstruction of phase 3 with existing Sufi shrines (marked in red dots); (d) Kōm ad-Dikka. Reconstruction of phase 4; (e) Kōm ad-Dikka. Reconstruction of phase 5.

\subsection{Second Morphological Phase}

The second phase begins in the seventh century AD, where the city's ancient physiognomy altered immensely; the traces of the orthogonal roads disappeared and a sinuous urban form emerged. This urban change is mostly detectible in travel book descriptions and maps. The various cartographic maps of Alexandria that were illustrated until the mid-sixteenth century don't explicitly mention the neighborhood. Still, two assumptive scenarios can be derived from them. The first one arises with the help of the historical map by Johann Helffrich. Based on his perspective map of 1566 and his travelogue description, the illustrated spine comprising the non-indigenous merchants' Fonticum can be assumed as the early nascence of Sūq Kōm ad-Dikka—the current Saiyid Darwīš street. The second scenario is based on the presumption of the morphology of the same spine, yet not upon a commercial genesis but a religious one. On the current Saiyid Darwīš street stands the mosque of Sīdī Surūr, where his shrine is located. It can be presumed that the spine of the current Saiyid Darwīš street first originated upon settlements next to Sufi Figures (Figure 7b).

\subsection{Third Morphological Phase}

The third phase proceeds with the two above-mentioned scenarios and is placed between the mid-sixteenth century and the end of the eighteenth century. The commercial genesis proceeds with a probable development of the original path of Sūq Kōm ad-Dikka into a village, based on Vansleb's description of the Jardin du Marchand-in the 17th century-and the concurrent illustrations on historical maps. The first survey map of the city of Alexandria, conducted during the French expedition in 1798, is the first map to clearly illustrate the urban fabric of the residential area. Based on this map, it can be deduced how the street path developed between the state of 1566 until 1798 . During this phase, new sinuous streets were formed and branched off the main spine of the current Saiyid Darwīš street. Among these branching streets are the current Sīdī Quštum that is perpendicular to the present Saiyid Darwīš street, Sīdī Alī al-Badawīi, and Sīdī Mihriz. Their origin, history and 
importance are believed to be related to the location of the shrines of Sīdī Mihriz and Sīdī Qušțum. Both shrines are located along the above-mentioned streets, which in turn justify the urban progression based on the religious scenario (Figure 7c).

\subsection{Fourth Morphological Phase}

The historical map of 1855 by Charles Muller best illustrates the ensuing development of the historical settlement after 1798. This fourth phase is between the end of the eighteenth century and mid-nineteenth century and witnesses the main readable footprint of the sinuous urban structure. Both probable scenarios don't continue separately but merge into one. During this phase, Saiyid Darwīs street extends further, whereas other byways branch off from it (Figure 7d). From the main spine of the current Sīdī Quštum street other paths branched such as Sīdī Mihriz, the current street of Ibn Nubātā, and al-Fasqiyia. These later developed into subsequent main access streets; their significance as main access streets can also be justified by the existing Sufi shrines. After 1855, Le Conseil d'Ornato applied the first urban adjustments in Kōm ad-Dikka. This included the reconstruction traces of the antique L1 road-the current Fouad street—regaining its role as Alexandria's main road.

\subsection{Fifth Morphological Phase}

The fifth phase covers the urban enclosure with the westernized urban vicinity-from 1855 until mid-twentieth century (Figure 7e). These changes mark the explicit juxtaposition of the two western and sinuous urban form. During the early nineteenth century part of the southern city gate was demolished and altered with the current 'Omar Tusun street. In the historical neighborhood, more byways extended from the sinuous pattern into the current Fouad street, to the north, and the current 'Omar Tusun, to the south. One of them is ad-Damāminni street; based on the reconstruction map of Noack, it is probably located above the traces of an ancient street. The city map of 1907 displays the enclosure application of the sinuous fabric by the new westernized streets. These are the eastern street

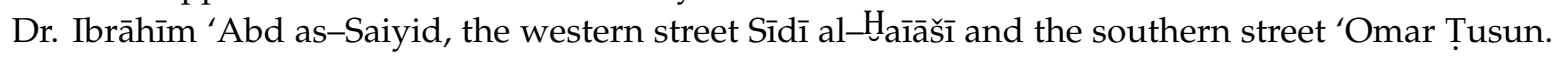
This phase marks the current predominant urban formation of Kōm ad-Dikka. Between the early twentieth century and today, little urban development has changed. The four perpendicular new main access roads of Fouad street in the north, 'Omar Ṭusun in the south, Dr. Ibrāhīm 'Abd as-Saiyid in the east and Sīdī al- $\mathrm{H}_{\mathrm{a}} \overline{\mathrm{i}} \mathrm{a} s \overline{\mathrm{s}}$ in the west frame have morphed completely organically.

This example of the urban morphology of Kōm ad-Dikka can be assumedly found in other examples, not only in Egypt, but in the surrounding Mediterranean and Arab region. Accordingly, comparable analysis can be undertaken to further study the relation between such an integrated social and urban juxtaposition, where new urbanization is taking place while preserving older structures.

\section{Conclusions}

The historical residential quarter of Kōm ad-Dikka has a rectangle-elongated shape and is immediately recognizable with its urban non-uniform physiognomy. Generally characterized by two different urban patterns, it exemplifies two juxtaposing, yet complementary, urban forms and social groups. The first urban form comprises of sinuous street structure, probably dating back to the 16th century, and is inhabited by the social underclass. The second urban form was initially constructed for the social elite back in the nineteenth century and consists of a westernized orthogonal street structure. This westernized urban style encloses the sinuous urban structure and forms the framing enclosure of the medieval residential quarter. This enclosure is crossed by four perpendicular streets (Fouad Street,

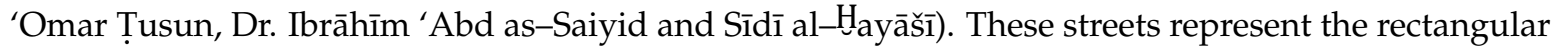
enclosure and current main access roads to the area. The entire complex of this residential district is an example of an extant urban and social system with a homogeneous heterogeneousness.

While conducting this type of research to uncover the morphology of Kōm ad-Dikka, it was important to note that most of the results are based on possibilities rather than explicit facts. Based on historical maps, as well as memoirs, the information extracted was sometimes unclear and confusing. 
Whether the current street of Saiyid Darwīš was a bazaar street, enclosed by gates at its ends, and represents the begin of the urban morphology of the neighborhood, still remains a hypothesis. The traces of the street gates are nowadays not visible. Based on the maps of 1798 and 1801 the positions of the former street gates can be assumed in two places: By the intersection west with the street Sīdi Mihriz or with the street al-Šaih ad-Darwīš, and to the east with the intersection Rustum Afandī street. Therefore, the morphological analysis and reconstruction results can be considered as interpretations more than definite facts. However, since this paper is mainly based on historical material and on sparse modern literature, it can be perceived as an added contribution towards the urban history of the city of Alexandria. This study is a gateway generating leads to be followed by further academic research and analytical representations, either for the city itself or for other comparable cities.

Funding: This paper is a reproduction of part of the author's unpublished master dissertation, written in 2014 in the German language, entitled: Kōm ad-Dikka Quarteruntersuchung, in the Technical University in Berlin, Germany. The entire master program was funded by the ERASMUS MUNDUS from 2012 until 2014. The master dissertation was under the supervision of Dorothée Sack and Ralph Bodenstein. The author has revised and developed the first part of the dissertation to present this paper in the English language to expand the utilization of its content to a wider range of researchers. The author is a current scholarship holder from the German Academic Exchange Service (DAAD) at the Bauhaus University Weimar in Germany as a PhD candidate under the supervision of Hans-Rudolf Meier and Ralph Bodenstein.

Acknowledgments: I wish to thank the institutional support that encouraged the author to work on this publication: Bauhaus University Weimar in Germany, the Alexandria University, and the AlexMed Research Center in Egypt.

Conflicts of Interest: The author declares no conflict of interest.

\section{References and Notes}

1. Author's Note: The Romanization from Arabic to English Is Based on the Rules of the Library of Congress. Available online: https:/ / www.loc.gov/catdir/cpso/romanization/arabic.pdf (accessed on 3 May 2018).

2. The Former Western Mound Is Now an Archaeological Site $12 \mathrm{~m}$ below Sea Level with Ongoing Excavations; Polish Center for Mediterranean Archaeology: Warsaw, Poland, 2018.

3. The Turkish Town Is an Artificial Peninsula Located between the Alexandrian Eastern and Western Harbor. Compare Building Typologies. In Alexandrie: Une Architecture Ottomane; Annaloro, M.; Lange, G. (Eds.) Éditions Parenthèses: Marseille, France, 2011.

4. Kom el Dekka et Non Kom el Dick, Comme il Est Communément Appelé, Est le Nom Donné à Une Butte au Centre de la Ville d'Alexandrie Aujourd'hui Rasée. Kom el Dekka et Non Kom el Dick Est le Vrai Nom Arabe' Lackany, Radames. Notes Sur Quelques Nomenclature Alexandrines. In Cahiers d'Alexandrie. Série II Fascicule 1. Alexandria; Le Centre d'Études Alexandrines-CEA: Alexandria, Egypt, 1964; p. 58. Available online: http:/ / www.cealex.org/pfe/diffusion/PFEWeb/pfe_009/PFE_009_002_w.pdf (accessed on 30 May 2018).

5. In His Book, El-Falaki Identifies It as 'Com-el-Dikkéh' on Page 57 and 'Com-el-Dikeh' on Page 20. M. El-Falaki, Mémoire Sur l'antique Alexandrie, Ses Faubourgs et Environs Découverts, Par Les Fouilles, Sondages, Nivellements et Autres Recherches (Bianco Luno, 1872). Available online: http:/ /www.cealex. org/sitecealex/diffusion/etud_anc_alex/LVR_000021_w.pdf (accessed on 25 May 2018).

6. Langenscheidts Handwörterbuch Arabisch-Deutsch; Langenscheidt KG: Berlin, Germany; München, Germany, 1996.

7. Strabo. The Geography of Strabo VIII, Book XVII; Harvard University Press: Cambridge, MA, USA, 1967.

8. El-Falaki, M. Mémoire Sur l'antique Alexandrie, Ses Faubourgs et Environs Découverts, Par Les Fouilles, Sondages, Nivellements et Autres Recherches (Bianco Luno, 1872), 57. Available online: http:/ /www.cealex. org/sitecealex/diffusion/etud_anc_alex/LVR_000021_w.pdf (accessed on 25 May 2018).

9. Clot-Bey, A. Aperçu Général Sur l'Égypte. (Fortin, Masson et cie, 1840), 194. Available online: https: / / archive.org/details/b22018992_0001 (accessed on 30 March 2018).

10. Haas, C. Alexandria in Late Antiquity: Topography and Social Conflict; The Johns Hopkins University Press: Baltimore, MD, USA, 1997. 
11. Grimm, G. City Planning? In Alexandria and Alexandrianism; Getty Publications: Los Angeles, CA, USA, 1996. Available online: http:/ / d2aohiyo3d3idm.cloudfront.net/publications/virtuallibrary /0892362928.pdf (accessed on 30 March 2018).

12. Damir, M. Kōm ad-Dikka Quarteruntersuchung. Master's Thesis, Technical University Berlin, Berlin, Germany, 2014.

13. Hoepfner, W.; Schwandner, E.L. Haus und Stadt im klassischen Griechenland; Deutscher Kunstverlag: Berlin, Germany, 1986; pp. 240-241.

14. In His Book, El-Falaki Refers to It as the Paneum, Wherein Other Literature It Is Referred to as Paneium (Strabo. The Geography of Strabo VIII, Book XVII. Translated by Jones HL. (Harvard University Press, 1967), 41. and R. McLeod, The Library of Alexandria: Centre of Learning in the Ancient World. (Tauris I.B., 2005, 40).

15. The Translator Points out that the Paneium Is a Sanctuary of the God Pan. The Geography of Strabo VIII, Book XVII; Warmington, E.H.; Page, T.E.; Rouse, W.H.D.; Capps, E.; Post, L.A. (Eds.) Harvard University Press: Cambridge, MA, USA, 1967; p. 41.

16. Majcherek, G. The Auditoria on Kom el-Dikka: A glimpse of late antique education in Alexandria. In Proceedings of the Twentyfifth International Congress of Papyrology, Ann Arbor, MI, USA, 29 July-4 August 2007; Volume 9, p. 471.

17. McKenzie, J. The Architecture of Alexandria and Egypt c. 300 BC to AD 700; Yale University Press: New Haven, CT, USA, 2007.

18. McKenzie, J. The Architecture of Alexandria and Egypt c. 300 BC to AD 700; Yale University Press: New Haven, CT, USA, 2007; p. 10.

19. Forster, E.M. Alexandria: A History and a Guide; Supreme Council of Culture: Cairo Governorate, Egypt, 1974; p. 124.

20. Sālim, A.A. Tarì h̀ Al-'Iskandariyia Wa Hadāratihā F̄̄ Al-'Asr Al-'Islamī. In The History and Culture of Alexandria in the Islamic Era; Mu'assasat Ash-Shabāb Al-Gāmi'1̄yah: Alexandria, Egypt, 1982; pp. 91-92. NOTE: Sālim references the information based on An-Nūwīrī Al-Iskandarānī' publication Kitāb Al-Ilmām: Bil-I’lām Fīmā Ğarat Bihi Al-Aḥkām Wa Al-Umūr Al-Maqdò̄yah Fī Waq'ä̈ Al-Iskandarīyah. 'Ațiyah, A.S., Ed.; Osmania Oriental Publications Bureau, Osmania University: Hyderabad, India, 1970; p. 77. However, since this book is published in 4 parts, Sālim does not specify which one the information is extracted. The author was able to access parts three and four where the information is not found. Another publication confirms the information about the Arab tribe 'Lakhm' in R. Lackany, Notes sur quelques nomenclature Alexandrines. In Cahiers d'Alexandrie; Le Centre d'Études Alexandrines-CEA: Alexandrie, Egypt, 1964; p. 59.

21. Kulicka, E. The Moslem Cemeteries on Kom El-Dikka in Alexandria: Excavation Season 2004/2005 Polish Archaeology in the Mediterranean Journal Online. (PAM 18, 2005). Available online: http:/ /www.pcma.uw. edu.pl/wp\&\#x2013;content/uploads/pam/PAM_2005_XVII/261.pdf (accessed on 25 May 2018).

22. For More Information about the Shrines-Maqām. See Damir, M. Kōm Ad-Dikka Quarteruntersuchung. Master's Thesis, Technical University Berlin, Berlin, Germany, 2014; pp. 106-124.

23. Véronique, F. Les céramiques médiévales d'Alexandrie: Un témoignage Archéologique D'importance. In Alexandrie Médiévale: Tome 1; Décobert, C., Empereur, J.-Y., Eds.; Institut Français D’archéologie Orientale du Caire-IFAO: Cairo, Egypt, 1999; p. 60.

24. Zsolt, K. Polish Research in Alexandria, Past Research, Layout I. 2007, p. 118. Available online: http: //www.pcma.uw.edu.pl/wp-content/uploads/template/main/img/lat70/book70_10.pdf (accessed on 21 May 2018).

25. Check Planche XIII. Carte particulière de la vieille et la nouvelle Alexandrie et des ports 1738. In Atlas Historique de La Ville et Des Ports d'Alexandrie; Jondet, G. (Ed.) Institut Français D’archéologie Orientale du Caire-IFAO: Cairo, Egypt, 1921. Available online: http://www.cealex.org/sitecealex/diffusion/etud_anc_ alex/LVR_000025_w.pdf (accessed on 22 May 2018).

26. The oldest isometric maps of Alexandria were drawn back at the end of the 15th century. In 1611, the English traveler George Sandys reports that Pierre Belon's Alexandria map of 1554 represents a more accurate image of the city than the previous ones. The map version of Johann Helffrich includes copies of multiple illustrative scenes from the map of Pierre Belon. 
27. Helffrich, J. Kurtzer Vnd Warhafftiger Bericht von Der Reyß Aus Venedig Nach Hierusalem, von Dannen Inn Aegypten Auff Den Berg Sinai, Alcair, Alexandria und Folgends Widerumb Gen Venedig; Berwaldts, J., Ed.; Erben: Leipzig, Germany, 1579; p. 218.

28. Abu-Lughod, J. Before European Hegemony: The World System A.D. 1250-1350; Oxford University Press: Oxford, UK, 1991; p. 228.

29. Bacque-Grammont, J.; Dankoff, R. D'Alexandrie à Rosette D'après La Relation de Voyage d'Evliya Celebi; Institut Français d'Etudes Anatoliennes: Istanbul, Turkey, 2001; p. 30.

30. Müller-Wiener, M. Eine Stadtgeschichte Alexandrias von 564/1169 Bis in Die Mitte Des 9/15. Jahrhunderts: Verwaltung Und Innerstädtische Organisationsformen; Klaus-Schwarz-Vlg: Berlin, Germany, 1992; pp. 250-251.

31. Awad, M.F. The Impact of Economic Change on the Structure and Function of the Building Industry in Egypt (1920-1985). Ph.D. Thesis, Alexandria University, Alexandria, Egypt, 1992; p. 263.

32. Except for the traces of L1, no urban or architectural traces have survived.

33. Forster, E.M. Alexandria: A History and a Guide; Supreme Council of Culture: Cairo Governorate, Egypt, 1974; p. 117.

34. Bremond, G. Voyage En Egypte de Gabriel Bremond, 1643-1645; Institut Français D'archéologie Orientale du Caire-IFAO: Cairo, Egypt, 1974; p. 27.

35. See Cadastral map of Alexandria, Block 578. Surveyed in January 1937. Published by the Survey of Egypt. Scale 1:500.

36. See Planchet XIV by, R. Pococke, 'A Plan of Alexandria'. 1742. in Jondet, Gaston. Atlas Historique de La Ville et Des Ports d'Alexandrie. (l'Institut Français D'archéologie Orientale, 1921). Available online: http:/ / www.cealex.org/sitecealex/diffusion/etud_anc_alex/LVR_000025_w.pdf (accessed on 25 May 2018).

37. In a paper by Niall Christie, the example of Funduq Al-Bayd Wa-Al-Qașab that dates back to the fourteenth century is described and reconstructed upon historical sources. She cites that it was located 'on the southern side of the Mahajjah al-'Uzmá, the main road that runs from the Rosetta Gate at the east end of Alexandria to the Green Gate at the west end'. This also supports the hypothesis that Kōm ad-Dikka might have been a bazaar or at least a settlement to serve one. Christie, N. Reconstructing Life in Medieval Alexandria from an Eighth/Fourteenth Century Waqf Document. Mamlūk Stud. Review 2004, III, 165.

38. This paper only focuses on documenting the urban morphology and is therefore not mentioning the underground water system. For more information, please see Hairy, I. Du Nil à Alexandrie, Histoires D'eau; Le Centre d'Études Alexandrines-CEA: Alexandria, Egypt, 2011. Damir, M. Kōm Ad-Dikka Quarteruntersuchung. Master's Thesis, Technical University Berlin, Berlin, Germany; pp. 20-58.

39. Vansleb, J.M. Nouvelle Relation, en Forme de Journal, d'un Voyage Fait en Egypte. En 1672 E 1673; Estienne Michallet: Lyon, France, 1677; p. 182.

40. Image Library. Map of Alexandria. Available online: http://www.alexanderstomb.com/main/ imageslibrary/maps/alexmaplemaitre1848.jpg (accessed on 3 May 2018).

41. Ramaḍān, A.A. Tarị Al-Misriyah Al-'Āmah Lil-Kitāb: Cairo, Egyot, 1993; p. 92.

42. The best study of Le Conseil d'Ornato is by Michael J. Reimer in his published paper. Michael, J. Reorganizing Alexandria: The Origins and History of the Conseil d'Ornato. J. Urban Hist. 1993, 19, 55-83.

43. Reimer, M.J. Les Fondements de la Ville Moderne: Un Tableau Socio-Démographique Entre 1820 et 1850. Revue de l'Occident Musliman et de la Méditerranée, nr. 46. 1987, pp. 110-120. Available online: https: / /www.persee.fr/doc/remmm_0035--1474_1987_num_46_1_2194 (accessed on 25 May 2018).

44. The inhabitants of Egypt were divided into two groups: the indigenous inhabitants, in Arabic 'dakhil al-hukuma', comprised of $88.7 \%$, and the non-Arabs and Europeans with $11.3 \%$, in Arabic 'kharij al-hukuma'.

45. More information on the social relationships of Kōm ad-Dikka which was mostly characterized by the Nubian community can be found in M. Damir. Damir, M. Kōm ad-Dikka Quarteruntersuchung. Master's Thesis, Technical University Berlin, Berlin, Germany, 2014.

(C) 2018 by the author. Licensee MDPI, Basel, Switzerland. This article is an open access article distributed under the terms and conditions of the Creative Commons Attribution (CC BY) license (http://creativecommons.org/licenses/by/4.0/). 